\title{
An outbreak of VHSV (viral hemorrhagic septicemia virus) infection in farmed Japanese flounder Paralichthys olivaceus in Japan
}

\author{
Tadashi Isshiki ${ }^{1, *}$, Toyohiko Nishizawa ${ }^{2}$, Tatsuya Kobayashi ${ }^{3}$, Taizou Nagano1, \\ Teruo Miyazaki ${ }^{3}$
}

\author{
${ }^{1}$ Kagawa Prefectural Fisheries Experiment Station, Takamatsu, 761-0111, Japan \\ ${ }^{2}$ Faculty of Applied Biological Science, Hiroshima University, Higashihiroshima, 739-8528, Japan \\ ${ }^{3}$ Faculty of Bioresources, Mie University, 1515 Kamihama, Tsu, 514-8507, Japan
}

\begin{abstract}
A rhabdoviral disease occurred in farmed populations of market sized Japanese flounder (hirame) Paralichthys olivaceus in the Seto Inland Sea of Japan in 1996. The causative agent was identified as viral hemorrhagic septicemia virus (VHSV) based on morphological, immunological, and genetic analyses. Diseased fish that were artificially injected with a representative virus isolate showed the same pathological signs and high mortality as observed in the natural outbreak. This is the first report of an outbreak of VHSV infection in cultured fish in Japan. Clinical signs of diseased fish included dark body coloration, an expanded abdomen due to ascites, congested liver, splenomegaly, and a swollen kidney. Myocardial necrosis was most prominent and accompanied by inflammatory reactions. Necrotic lesions also occurred in the liver, spleen and hematopoietic tissue, and were accompanied by circulatory disturbances due to cardiac failure. Hemorrhagic lesions did not always appear in the lateral musculature. Transmission electron microscopy revealed many rhabdovirus particles and associated inclusion bodies containing nucleocapsids in the necrotized myocardium. The histopathological findings indicated that the necrotizing myocarditis could be considered a pathognomonic sign of VHSV infection in Japanese flounder.
\end{abstract}

KEY WORDS: Viral hemorrhagic septicemia - Viral hemorrhagic septicemia virus Paralichthys olivaceus $\cdot$ Japanese flounder $\cdot$ Hirame $\cdot$ Necrotizing myocarditis

\section{INTRODUCTION}

Viral hemorrhagic septicemia (VHS) has been a serious disease of farmed rainbow trout Oncorhynchus mykiss primarily in European countries. The causative agent, viral hemorrhagic septicemia virus (VHSV), has also been reported from other salmonid fishes in European countries since 1965 (Rasmussen 1965, Jørgensen 1980, Smail 1999) and North America since 1988 (Brunson et al. 1989, Winton et al. 1989, Amos et al. 1998). Outbreaks of VHSV infection has been reported

*E-mail: kagawafdl@pop06.odn.ne.jp in sea-farmed rainbow trout in France and Denmark (Castric \& de Kinkelin 1980, Horlyck et al. 1984), and sea-farmed turbot Scophthalmus maximus in Germany and Scotland (Schlotfeldt et al. 1991, Ross et al. 1994). In addition, since the early 1990s, VHSV has been increasingly detected in a wide range of wild marine species with or without disease in Europe and North America (Meyers \& Winton 1995, Mortensen et al. 1999, Smail 1999). Also, the existence of an epizootic due to VHSV in marine environments has been demonstrated in Pacific herring Clupea pallasi and turbot (Kocan et al. 1997, Snow \& Smail 1999). In 1999, VHSV was first isolated from wild Japanese flounder (hirame) Paralichthys olivaceus caught in the Wakasa Bay of 
Japan during a survey on the distribution of fish viruses in wild marine fishes (Takano et al. 2000).

Clinical signs and histopathological features of VHSV infection in some freshwater and marine fishes resemble those in rainbow trout. A common feature is the widespread hemorrhaging in the external and internal organs, although the severity of hemorrhaging varies among fish species. Rainbow trout displays most severe hemorrhagic lesions in the lateral musculature (Yasutake \& Rasmussen 1968, Yasutake 1970, 1975, Horlyck et al. 1984, Smail \& Munro 1989). Hemorrhagic lesions are also evident in pike Esox lucius (Meier \& Jørgensen 1980), sea bass Dicentrarchus labrax (Castric \& de Kinkelin 1984) and turbot (Ross et al. 1994), but are less obvious in Pacific herring (Kocan et al. 1997). Histopathologically, necrotic changes are observed in various visceral organs incluging the liver, spleen, hematopoietic tissue and pancreatic acini in many fish species except Pacific cod Gadus macrocephalus, which displays only dermal lesions (Meyers et al. 1992).

VHSV is a member of the family Rhabdoviridae, genus Novirhabdovirus, to which infectious hematopoietic necrosis virus (IHNV) and hirame rhabdovirus (HIRRV) belong (Walker et al. 2000). HIRRV, the causative agent of the HIRRV disease (HIRRVD), was widely distributed in farmed hirame and other marine fishes in Japan (Kimura \& Yoshimizu 1991, Nishizawa et al. 1991). HIRRV caused mass mortalities in farmed hirame in Japan during the 1980s (Kimura et al. 1986, 1989). The diseased fish usually displayed severe hemorrhage in the lateral musculature and in visceral organs accompanied by markedly necrotic lesions of the spleen and the hematopoietic tissue, which are very similar to those observed in the VHSV infections mentioned above.

During winter to spring of 1996, a rhabdoviral disease broke out in cultured hirame in the Inland Sea of Japan. Because the diseased hirame showed clinical signs a little different from those of HIRRVD, and results of serological and molecular biological tests of the rhabdovirus revealed differences to HIRRV, we previously thought that the virus was a new type of HIRRV. Recently, we were able to identify the virus as VHSV, which could not be considered identical with the isolate of VHSV from wild hirame reported by Takano et al. (2000). In the present paper, we report the isolation and identification of VHSV from cultured diseased hirame that had experienced mass mortality in 1996. We also induced experimental infections with a representative isolate of VHSV to determine its pathogenicity for hirame and describe the histological and ultrastructural pathologies for both naturally and experimentally infected fish. This is the first report of an outbreak of VHSV infection in cultured fish in Japan.

\section{MATERIALS AND METHODS}

Examinations of diseased hirame. Eleven diseased fish (295 to $575 \mathrm{~g}$ ) that were moribund or had just died were collected from 2 farming areas in the Seto Inland Sea of Japan during April 1996. After external and internal observations, the gills and body surface were examined microscopically for the presence of parasites and bacteria. Pieces of the brain, kidney and liver were cultured for bacteria on brain heart infusion agar plates (Nissui, Japan) supplemented with $2.0 \% \mathrm{NaCl}$ and incubated at $25^{\circ} \mathrm{C}$ for $7 \mathrm{~d}$. In addition, viral culture of the spleen tissues was done by first homogenizing with 9 volumes of Hanks' balanced salt solution (Hanks'

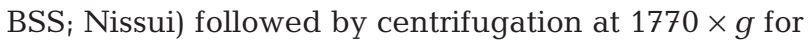
$15 \mathrm{~min}$ at $4^{\circ} \mathrm{C}$. The supernatant was diluted 5 times with Hanks' BSS and filtered through a $450 \mathrm{~nm}$ membrane filter. The filtrate was inoculated onto 6 fish cell lines: CHSE-214 (chinook salmon embryo: Lannan et al. 1984), RTG-2 (rainbow trout gonad: Wolf \& Quimby 1962), EPC (epithelioma papilosum cyprini: Tomasec \& Fijan 1971), FHM (fathead minnow: Gravell \& Malsburger 1965), BF-2 (blue gill fry: Wolf et al. 1966) and RSBK-2 (red sea bream kidney: Kusuda \& Kawarasaki 1993). The inoculated cells were incubated at 10 or $20^{\circ} \mathrm{C}$, and examined for the appearance of cytopathic effect (CPE).

Virus characterization. The RSBK-2 cells were markedly susceptible to VHSV isolates and were used to clone a representative isolate, KRRV-9601, by applying the end point dilution method 3 times. Virus strains of IHNV (ChAb strain), HIRRV (8401-H strain: Kimura et al. 1986) and VHSV (Obama \#25: Takano et al. 2000) were used as reference novirhabdoviruses and propagated in RSBK-2 cells. Rabbit antisera against IHNV (ChAb), HIRRV (8401 H: Kimura et al. 1986) and VHSV (DK-F59: Olesen \& Lorenzen 1999) were used in cross neutralization tests and for the analysis of viral structural proteins. Antisera against IHNV (ChAb) and VHSV (DK-F59) were kindly provided by Dr Yoshimizu (Hokkaido University) and Dr Olesen (Danish Veterinary Laboratory), respectively. Cell lines of CHSE-214, RTG-2, EPC, FHM, and BF-2 were tested for virus susceptibility. All cells were grown in Eagle's minimum essential medium (MEM, Nissui) supplemented with $10 \%$ fetal bovine serum (MEM 10) for cell growth and with $2 \%$ serum (MEM 2) for viral replication at $20^{\circ} \mathrm{C}$. Virus titer was measured by $50 \%$ tissue culture infectious dose $\left(\mathrm{TCID}_{50}\right)$ using a 96-well microplate (Falcon, USA) seeded with RSBK 2 cells after a $14 \mathrm{~d}$ incubation. The end points were calculated using the Behrens Kaber's method.

In the test for cell susceptibility, the KRRV-9601 isolate was serially diluted from $10^{0}$ to $10^{-10}$ with $50 \mu \mathrm{l}$ of MEM 2. Each dilution was inoculated into 4 wells of a 
96-well microplate having a monolayer of one of the above 6 cell lines. Inoculated cells were examined for CPE.

Optimun growth temperatures for the isolate KRRV 9601 were determined using $1 \mathrm{~cm}^{2}$ culture tubes (Nunc, Denmark) containing RSBK 2 cells that had been inoculated with the virus at a multiplicity of infection (MOI) of $0.01 \mathrm{TCID}_{50}$ cell $^{-1}$. The cultures were incubated at $5,10,15,20,25,30$ and $35^{\circ} \mathrm{C}$. At $0.25,0.5$, $1,2,3,5$ and $7 \mathrm{~d}$ post inoculation, the virus titers in each culture tube were eventually determined.

In cross neutralization tests, IHNV (ChAb), HIRRV (8401-H), VHSV (Obama \#25) and the isolate KRRV9601 were exposed to antisera against IHNV (ChAb), HIRRV (8401-H) and VHSV (DK-F59). Briefly, 2-fold serial dilutions of each antiserum were mixed with an equal volume of virus solution containing approximately $10^{2.0}$ TCID $_{50} 50 \mu^{-1}$ and incubated at room temperature for $1 \mathrm{~h}$. Aliquots of each mixture $(100 \mu \mathrm{l}$ well ${ }^{-1}$ ) were transferred to 2 wells of a 96-well microplate with FHM cell monolayers. The maximum dilution of antiserum to neutralize each virus was calculated after $14 \mathrm{~d}$ incubation at $20^{\circ} \mathrm{C}$.

Analysis of viral structural proteins for IHNV (ChAb), HIRRV (8401-H), VHSV (Obama \#25) and the isolate KRRV-9601 was done by first purifying the viruses from the virus-cultivated medium by centrifugation through a discontinuous gradient composed of 50, 35 and $20 \%$ (W/W) sucrose in ST buffer (20 mM Tris-HCl, $\mathrm{pH} 7.4,100 \mathrm{mM} \mathrm{NaCl})$. Viral structural proteins were analyzed by SDS-PAGE using $10 \%$ polyacrylamide gel electrophoresis under the reducing conditions of Laemmli (1970) and stained with silver nitrate. Proteins separated by SDS-PAGE were electroblotted onto nitrocellulose membrane by the procedure of Towbin et al. (1979) for immunostaining with antisera against IHNV (ChAb), HIRRV (8401-H) and VHSV (DK-F59), and then were visualized with an alkaline phosphatase conjugate substrate kit (Bio-Rad, USA) according to the manufacturer's instructions.

Polymerase chain reaction (PCR) amplification with 2 different primer sets, VG1-VD3 (Miller et al. 1998) and VM1sense-VM1anti (Takano et al. 2000) targeting VHSV G and M1 genes of VHSV, was done by extracting RNAs of the isolate KRRV-9601 from virus-cultured medium using an RNA extraction kit (Isogen-LS, Nippon Gene, Japan) according to the manufacturer's instructions. Reverse transcription and amplification reactions of the RT-PCR were performed under the same condition described by Takano et al. (2000), and the amplified products were analyzed by $1.5 \%$ agarose-TAE (40 mM Tris-acetate, $\mathrm{pH} 7.2$ and $1 \mathrm{mM}$ EDTA) gel electrophoresis.

Experimental infection. The pathogenicity of the isolate KRRV-9601 was examined using 3 sizes of hirame averaging 14, 124 and $1059 \mathrm{~g}$ in body weight (small, medium and large fish groups, respectively). Experimental fish that had never experienced the present disease were obtained from the Kagawa Prefectural Sea Farming Center. Ten fish of each size group were injected intraperitoneally with $10^{5.05} \mathrm{TCID}_{50} \mathrm{fish}^{-1}$ of the isolate KRRV-9601. Controls for each corresponding fish group were injected similarly with virus free MEM. After injection, the small, medium and large fish groups were reared in 30, 100 and 20001 aquaria containing seawater at $10 \pm 1^{\circ} \mathrm{C}$ for 15,24 and $60 \mathrm{~d}$, respectively. Clinical signs of disease and mortality were recorded daily. Moribund, dead and surviving fish were processed for histopathology, transmission electron microscopy (TEM), and for virus reisolation from pooled material of heart and spleen using RSBK2 cells.

Histopathology and TEM. The tissues including the heart, liver, spleen, kidney, gonad, brain, digestive tracts, gills, and lateral musculatures of both naturally and experimentally infected fish were fixed in $10 \%$ phosphate buffered formalin for histopathology. Fixed materials were embedded in paraffin wax and sectioned at 3 to $4 \mu \mathrm{m}$. Tissue sections were stained with Mayer's hematoxylin and eosin (H\&E), and Azan stains. Immunohistochemical staining was also done on tissue sections using an antiserum against KRRV9601 isolate and a VECTASTAIN Elite ABC kit (Vector, USA) according to the manufacturer's instructions. The remaining tissues pieces were fixed for TEM in a mixture of $2.5 \%$ glutaraldehyde and $2 \%$ paraformaldehyde in phosphate buffer $(\mathrm{pH} 7.4)$ at $4^{\circ} \mathrm{C}$. Fixed materials were rinsed 3 times in buffer and then they were post fixed in $2 \%$ osmium tetroxide, dehydrated through a graded ethanol series, and embedded in Epon epoxy resin. Virus infected RSBK-2 cells in a $25 \mathrm{~cm}^{2}$ culture flask (Falcon) were harvested and centrifuged at $200 \times g$ for $10 \mathrm{~min}$. The resulting pellet was fixed and processed for TEM. Ultrathin sections were stained with uranyl acetate and lead citrate, and observed at $80 \mathrm{kV}$ with a JEM-1200EX transmission electron microscope.

\section{RESULTS}

\section{Outbreaks and gross findings of diseased fish}

The flounder mortality occurred during the middle of March to May when water temperatures were between 8 and $15^{\circ} \mathrm{C}$. The cumulative mortality reached about 50 to $70 \%$ in 2 farming areas. Individual diseased fish usually showed a dark body coloration, an expanded abdomen due to ascites, pale gill coloration, and internally, clear ascitic fluid in the peritoneal and 


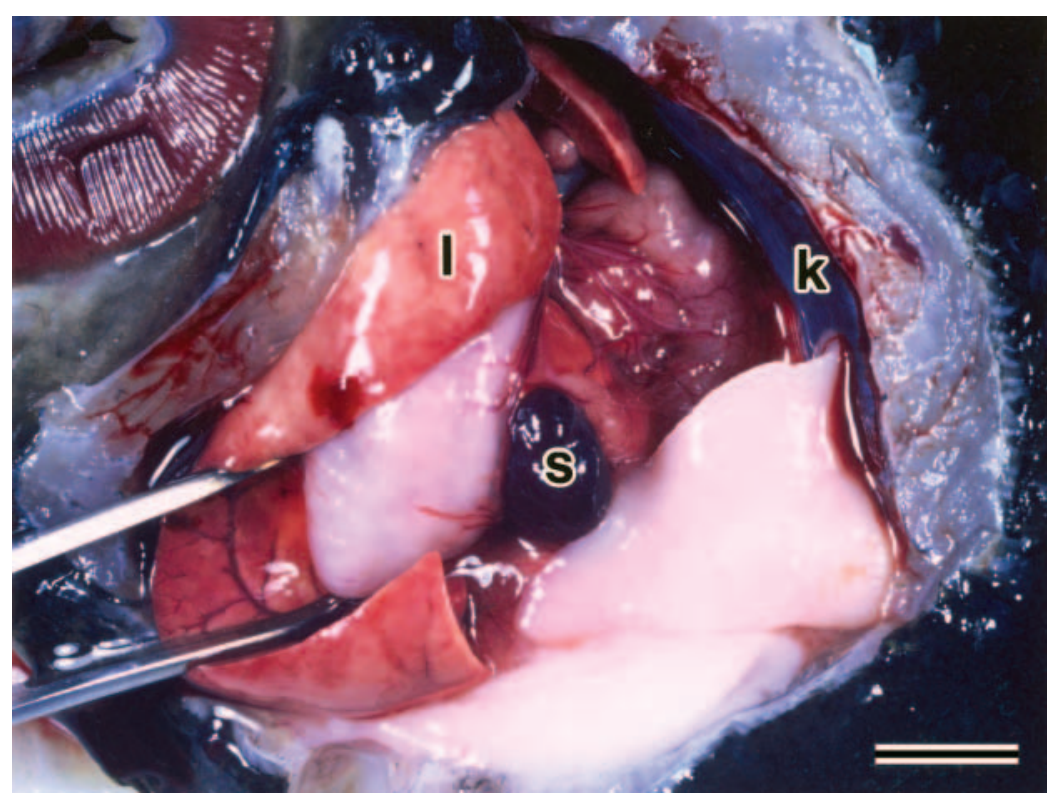

Fig. 1. Paralichthys olivaceus. A naturally diseased fish displays pale coloration of gills, accumulation of ascitic fluid, a congested liver (l), splenomegaly (s) and swollen kidney $(\mathrm{k})$. Scale bar $=1 \mathrm{~cm}$
RSBK-2 cells demonstrated many virus particles budding from the cell membrane. Bullet, cone or bacilliformshaped virions were present in extracellular or intracellular spaces. The virion possessed an envelope around a cross-striated nucleocapsid. The enveloped virions were 180 to $293 \mathrm{~nm}$ in length and 60 to $86 \mathrm{~nm}$ in diameter (Fig. 2A). These morphological features were typical of the family Rhabdoviridae. The infected cell cytoplasm also contained inclusion bodies composed of a granular substance, and often contained electron-dense nucleocapsid like structures, 160 to $620 \mathrm{~nm}$ in length, and 60 to $75 \mathrm{~nm}$ in diameter (Fig. 2B), which resembled those reported in RTG-2 cells infected with Danish strain F1 of VHSV from rainbow trout (Zwillenberg et al. 1965, de kinkelin \& Scherrer 1970).

Replication of the isolate KRRV-9601 in RSBK-2 cells at 7 selected tempera- pericardial cavities, a congested liver, splenomegaly, swollen kidney and occasional hemorrhage in the lateral musculature (Fig. 1). Although a few trichodinalike ciliates were observed on the gills of all fish examined, no bacteria were isolated from the brain, kidney or liver.

\section{Virus characterization}

The susceptibilities of 6 different cell lines to the isolate KRRV-9601 are shown in Table 1. The highest virus titer was observed in RSBK-2 cells followed by FHM and BF-2 cells. RTG-2 and CHSE-214 cells showed lower susceptibilities, and the least susceptible was the EPC cell line. CPE for virus infected RSBK-2 cells consisted of round cells after $3 \mathrm{~d}$ incubation at $20^{\circ} \mathrm{C}$ and after $5 \mathrm{~d}$ incubation at $10^{\circ} \mathrm{C}$. TEM of infected

Table 1. Susceptibility of various cell lines to the new isolate (VHSV)

\begin{tabular}{|lc|}
\hline Cell line & $\log _{10} \mathrm{TCID}_{50} \mathrm{ml}^{-1 \mathrm{a}}$ \\
\hline RSBK-2 & 8.80 \\
FHM & 8.05 \\
BF-2 & 7.55 \\
CHSE-214 & 4.55 \\
RTG-2 & 3.80 \\
EPC & 1.80 \\
${ }^{a}$ Virus titer was calculated after incubation at $20^{\circ} \mathrm{C}$ for $14 \mathrm{~d}$ \\
\hline
\end{tabular}

tures is shown in Fig. 3. The temperature range for virus replication was determined to have been between 5 and $20^{\circ} \mathrm{C}$. Virus replication was most rapid at $20^{\circ} \mathrm{C}$, but the maximum virus titer $\left(10^{9.8} \mathrm{TCID}_{50} \mathrm{ml}^{-1}\right)$ was obtained at $15^{\circ} \mathrm{C}$. No evidence of virus replication occurred at above $25^{\circ} \mathrm{C}$.

Results of viral neutralization tests are shown in Table 2. The KRRV-9601 isolate was efficiently neutralized with anti-VHSV (DK-F59) serum, but not with antiserum against IHNV or HIRRV. The isolate KRRV9601 was also positive for the indirect fluorescent anti-

Table 2. Cross neutralization of infectious hematopoietic necrosis virus (IHNV), hirame rhabdovirus (HIRRV) viral hemorrhagic septicemia virus (VHSV) and the newly isolated rhabdovirus KRRV-9601 with antisera against IHNV, HIRRV and VHSV

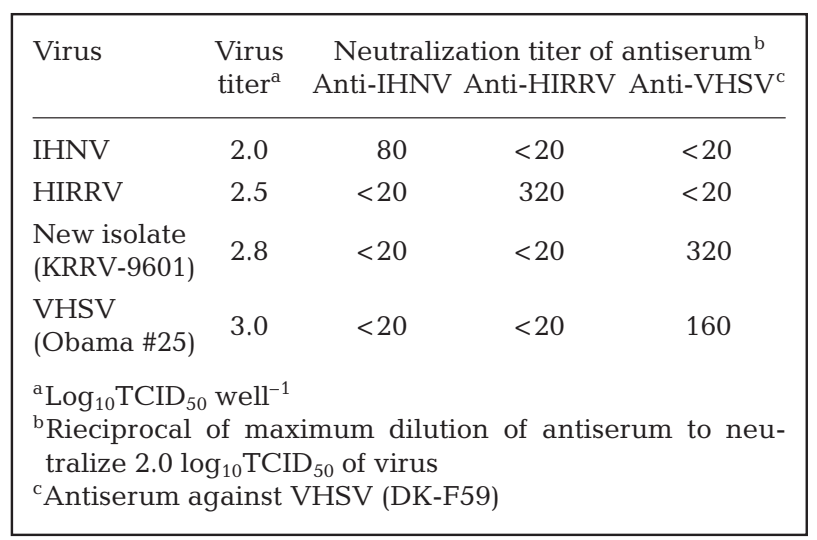



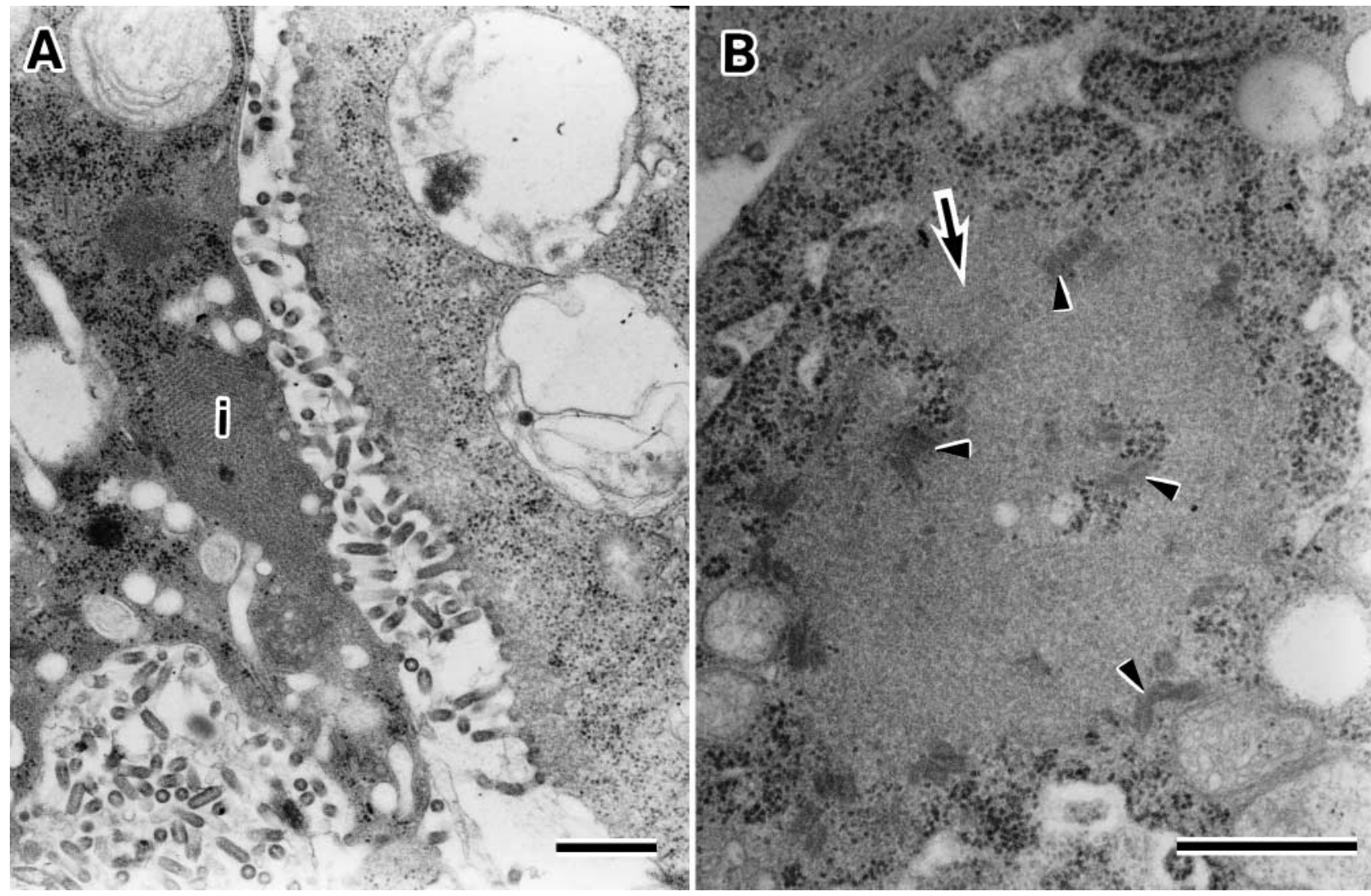

Fig. 2. Electron micrographs of RSBK-2 cells infected with VHSV. (A) Many virions with bullet, cone, or bacilliform shapes appear in extrecellular and intrecellular spaces. Budding is prominent in the cytoplasmic membranes. Inclusion bodies (i) are formed in the infected cells. (B) Higher magnification of an intracytoplasmic inclusion body with granular substance (large arrow) and nucleocapsid-like structures (arrowheads). Scale bars $=500 \mathrm{~nm}$

body technique (IFAT) using the anti-VHSV (DK-F59) serum, but not with anti-IHNV or HIRRV serum (data not shown).

Results of SDS-PAGE and Western blot analyses of viral structural proteins are shown in Fig. 4. Virus particles of the isolate KRRV-9601 were composed of 5 structural proteins, and its SDS-PAGE pattern was more similar to that of VHSV Obama \#25 than those of IHNV and HIRRV. However, slight differences were observed in the relative mobility of the G, M1 and M2 proteins between VHSV Obama \#25 and the isolate KRRV-9601. In the Western blot analyses (Fig. 4), antisera against IHNV and HIRRV showed extensive cross-reactions with IHNV and HIRRV but almost no cross-reaction with the isolates KRRV-9601 and VHSV Obama \#25. Conversely, anti-VHSV (DK-F59) serum showed cross-reaction of the G, N, M1 and M2 proteins of the isolate KRRV-9601 and VHSV Obama \#25, but not with those of IHNV or HIRRV.

In the PCR amplification with the VG1 and VD3 primer sets, a PCR product approximately 700 bases long was amplified from the genome of the isolate

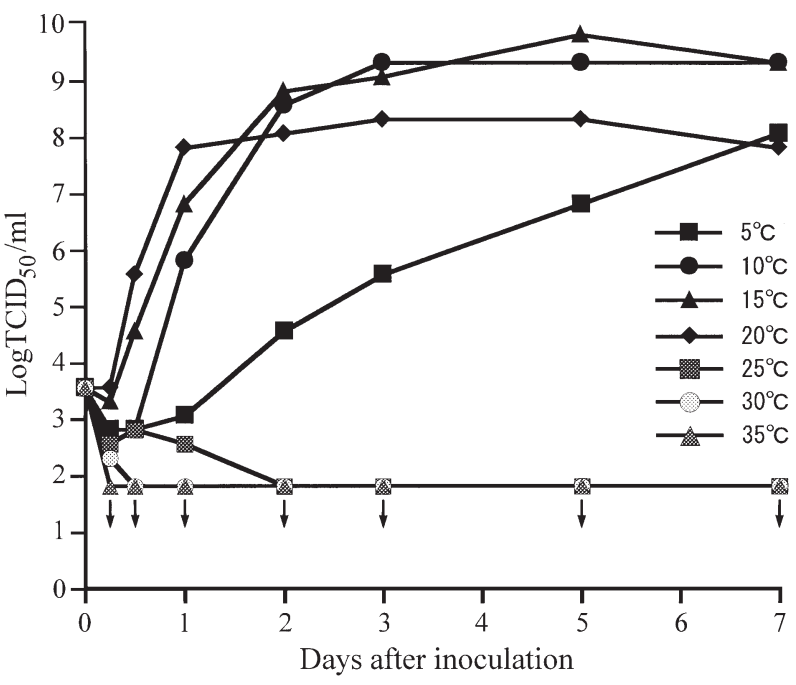

Fig. 3. Replication of the new isolate (VHSV) in the RSBK-2 cell line that was inoculated with the virus at a multiplicity of infection (MOI) of $0.01 \mathrm{TCID}_{50} \mathrm{cell}^{-1}$ and was incubated at 7 selected temperatures. Data below detection limit $\left(<10^{1.8} \mathrm{TCID}_{50} \mathrm{ml}^{-1}\right)$ are indicated by arrows 


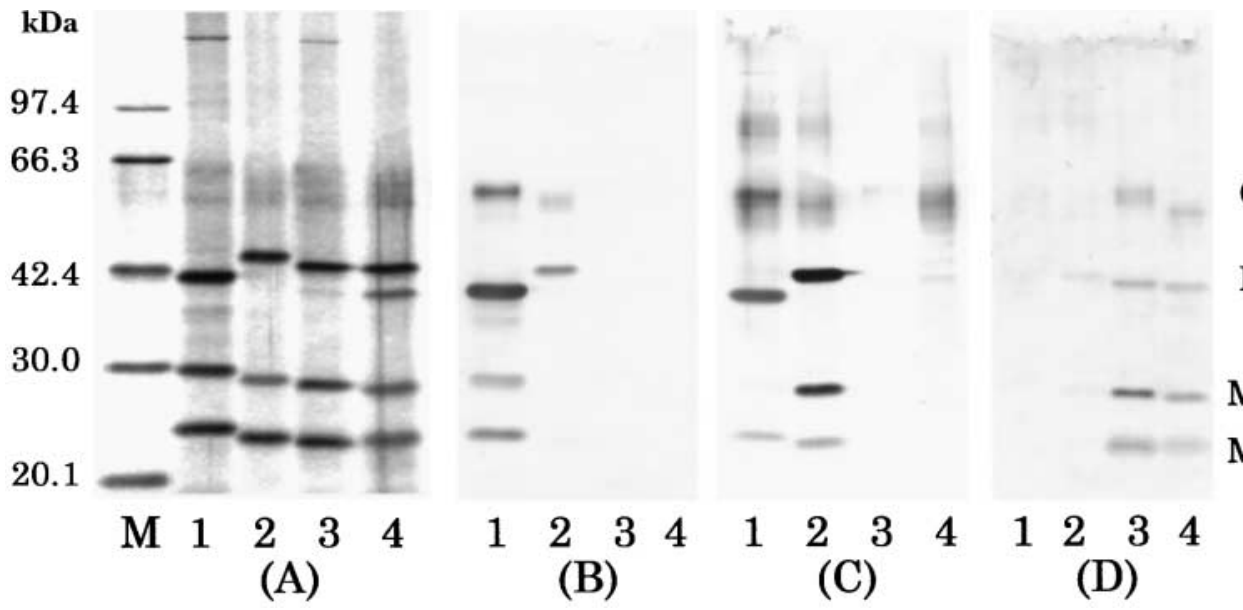

Fig. 4. SDS-PAGE and Western blot analysis of structural proteins of IHNV, HIRRV, VHSV and the newly isolated rhabdovirus KRRV-9601.

G (A) SDS-PAGE, (B to D) Western blotting with (B) antiserum against IHNV, N (C) anti-HIRRV serum, (D) anti-VHSV serum (DK-F59). Lane M: molecular weight M1 marker, lane 1: IHNV, lane 2: HIRRV, lane 3: the rhabM2 dovirus KRRV-9601, lane 4: VHSV. G, N, M1 and M2 are glycoprotein, nucleoprotein, matrix protein 1 and matrix protein 2 , respectively

KRRV-9601 and VHSV Obama \#25; however, no PCR product was observed from HIRRV or IHNV genomes. In the case of the primer set targeting the VHSV M1 protein gene, an approximately 660-base-long PCR product was observed in both isolates KRRV-9601 and VHSV Obama \#25. The size of each PCR product was consistent with that of target regions for each primer set (data not shown).

\section{Experimental infection}

Cumulative mortalities of artificially infected fish are shown in Fig. 5. The cumulative mortality of the small and medium groups reached $100 \%$ within 15 and $24 \mathrm{~d}$ respectively, while $60 \%$ mortality occurred in the large group. The external and internal signs of moribund or dead fish were generally similar to those of naturally diseased fish except for some large fish that showed

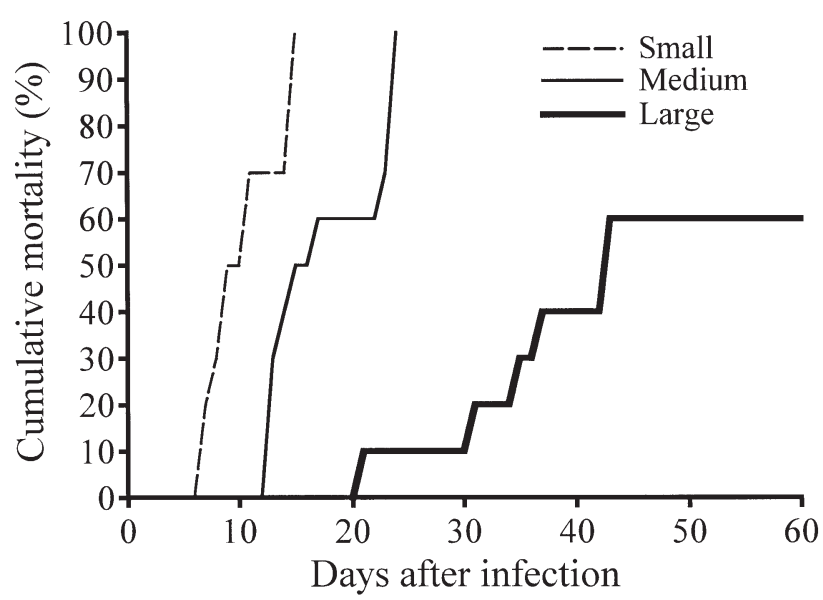

Fig. 5. Paralichthys olivaceus. Cumulative mortality of small $(14 \mathrm{~g})$, medium (124 g) and large (1059 g) hirame that were injected intraperitoneally with $10^{5.05} \mathrm{TCID}_{50}$ fish $^{-1}$ of the new isolate (VHSV) at $10^{\circ} \mathrm{C}$. No mortality occurred in control groups of fish (not shown) hemorrhage in the lateral musculature and/or the liver. The virus was reisolated from all infected moribund and dead fish. In contrast, the control fish did not die during the experiment and tested virus-negative.

\section{Histopathological and electron microscopic features of naturally and experimentally diseased fish}

The most prominent pathological changes were observed in the heart tissues of both naturally and experimentally diseased fish. Many muscle fibers in the inner layer of the myocardium were necrotized showing karyorrhexis, karyopyknosis and lytic myofibrils accompanied by infiltration of many inflammatory cells (Fig. 6A). In the narrow outer layer of the myocardium, muscle fibers were extensively necrotized and followed by fibrin deposition (Fig. 6B,C). Immunohistochemical staining distinctly displayed positive reactions demonstrating the presence of virus antigens in necrotic muscle fibers (see Fig. 8A). Furthermore, the epicardium was edematously dissociated and infiltrated by many inflammatory cells.

Many necrotic foci were present in the hematopoietic tissue accompanied by edema and dilation of sinusoids, while the renal tubular epithelia were edematously separated (Fig. 6D). The necrotic foci often exhibited fibrin deposition and slight hemorrhage (Fig. 7A). Renal epithelial cells often contained hyaline droplets. Splenic tissues were usually edematous and congested having necrotic foci and fibrin deposition or slight hemorrhage in the pulp (Fig. 7B). Sheathed arteries were also necrotized and accompanied by fibrin deposition. These necrotic foci in the splenic tissues displayed reactions in immunohistochemical staining as well as in those of the hematopoietic tissues. Congestion of hepatic blood vessels and sinusoids were present in the livers of naturally diseased fish, while hepatocytes appeared unaffected. In contrast, the livers from ex- 


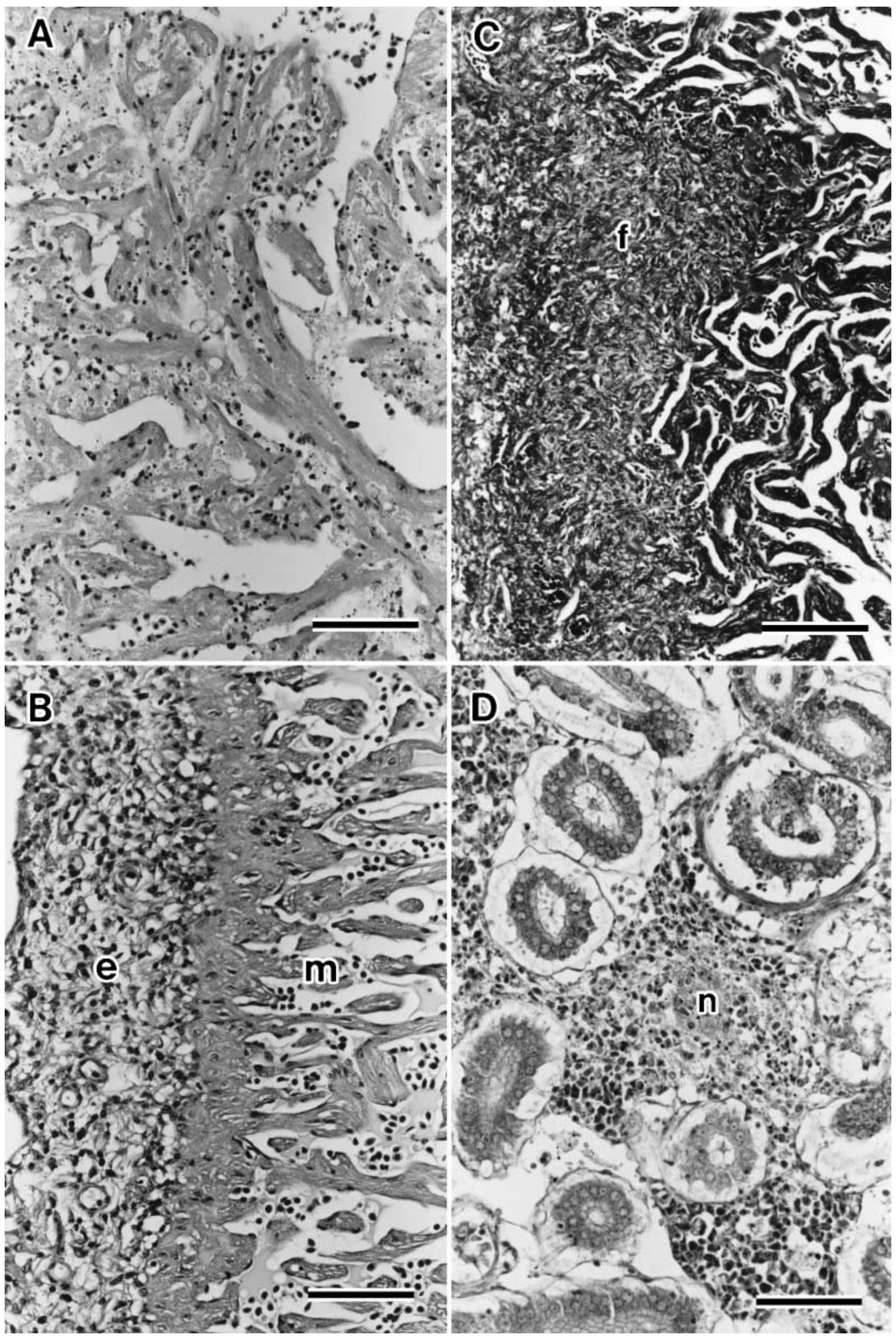

Fig. 6. Paralichthys olivaceus in natural outbreak. (A) The myocardium of the ventricle displays extensive necrosis. Necrotized muscle fibers with karyopyknosis and karyorrhexis are partially liquefied. H\&E. Scale bar $=50 \mu m$. (B) The epicardium (e) of the ventricle is edematous and infiltrated with many infammatory cells. The outerlayer of the necrotic myocardium (m) shows fibrin deposition. H\&E. Scale bar $=50 \mu \mathrm{m}$. (C) Azan stain illustrates fibrin (f) in the outerlayer of the necrotic myocardium. Azan. Scale bar $=100 \mu \mathrm{m}$. (D) The hematopoietic tissue is focally necrotiized(n) with minor hemorrhage in the kidney. Most of renal epithelia are edematously separated from basal lamina. H\&E. Scale bar $=50 \mu \mathrm{m}$ 


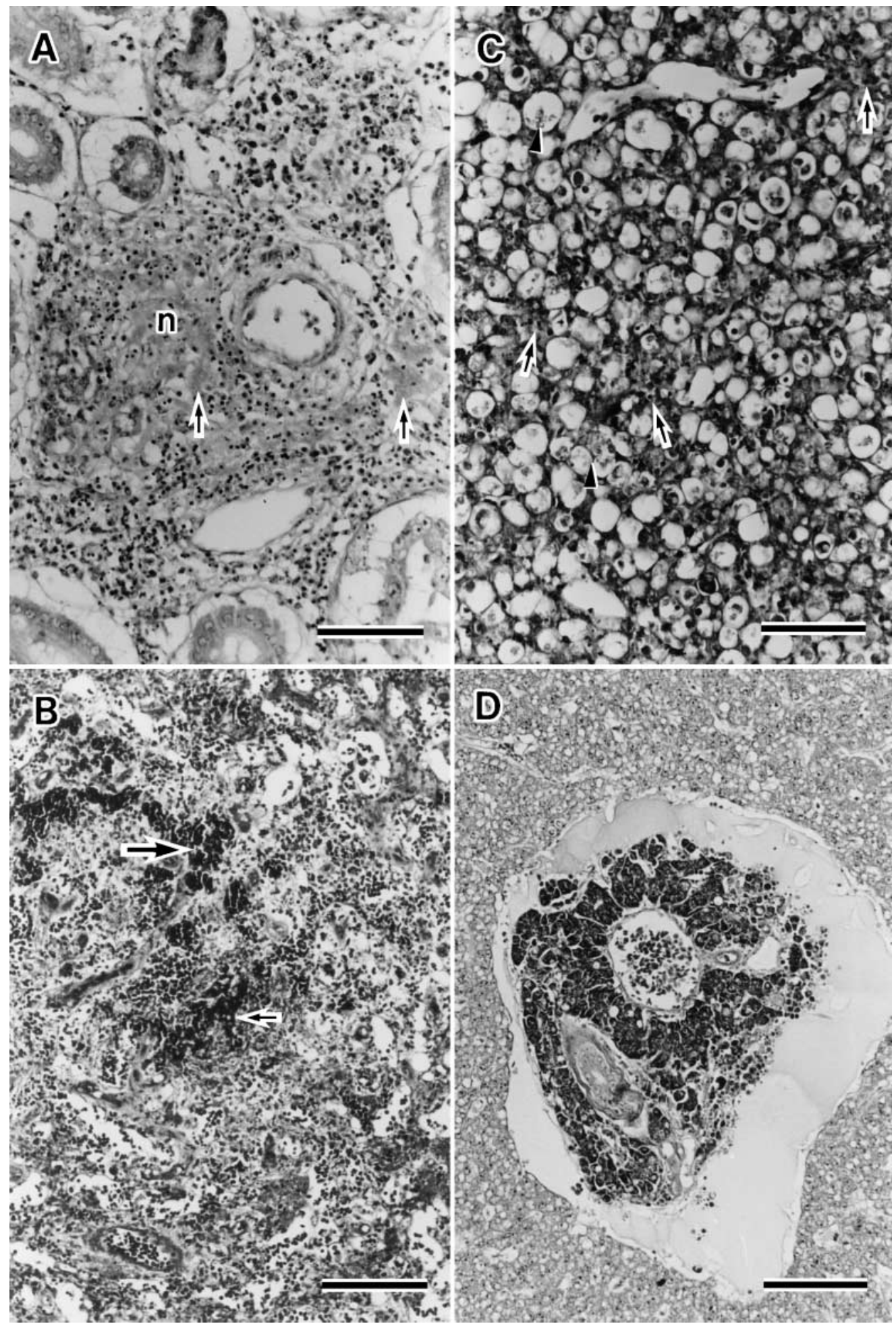

Fig. 7. Paralichthys olivaceus in experimental infection. (A) The hematopoietic tissue shows focal necrosis (n) with fibrin deposition (arrows) and minor hemorrhage in the kidney. Renal epithelia are edematously separated from basal lamina. H\&E. Scale bar $=50 \mu \mathrm{m}$. (B) The spleen displays focal necrosis with slight hemorrhage in the pulps (large arrow), fibrin deposition in the sheathed arteries (small arrow), and venous sinuses dilatation. Azan. Scale bar $=100 \mu \mathrm{m}$. (C) Many hepatocytes are necrotized with karyopyknosis (arrows) and fragmented. Fragmented cells are replaced by vacuoles containing cellular debris (arrowheads). H\&E. Scale bar $=50 \mu \mathrm{m}$. (D) Hepatopancreas is edematous and pancreatic acinar cells show atrophy or necrosis. H\&E. 
perimentally diseased fish contained large numbers of necrotized hepatocytes that were replaced by vacuolar spaces (Fig. 7C). Necrotized hepatocytes and fragments were positive in immunohistochemical staining while vacuoles derived from fat droplets were negative. Furthermore, the intrahepatic acinar cells of the pancreas were also necrotic and atrophic from compression by accumulation of fibrin like materials around the acini (Fig. 7D). The intestines and gonads occasionally displayed congested blood vessels. Hemorrhagic foci between muscle fibers were present in the lateral musculature of some artificially infected large fish. Gills and brain showed no obvious histopathological changes.

TEM of infected cardiac muscle showed many virus particles in extracellular or intracellular spaces, and inclusion bodies composed of granular and fibrous material accompanied by many nucleocapsids within myofibrils (Fig. 8B,C). The virions were bullet-, coneor bacilliform-shaped and enveloped with a crossstriated nucleocapsid. The enveloped virions were 180 to $505 \mathrm{~nm}$ in length and 60 to $82 \mathrm{~nm}$ in diameter. In these necrotized muscle cells, myofibrils were fragmented and deposited by fibrin, and mitochondria were degenerated. TEM of necrotized cells of the hematopoietic tissue and spleen also displayed virions among the fragmented organella (Fig. 8D).

\section{DISCUSSION}

The causative virus, KRRV-9601 isolate, that caused mass mortality of cultured hirame in Japan during 1996, morphologically showed enveloped and bullet shaped virions (180 to $293 \times 60$ to $86 \mathrm{~nm}$ ) in the extracellular or intracellular spaces of infected cells. The virion was composed of 5 structural proteins $(\mathrm{L}, \mathrm{G}, \mathrm{N}$, M1 and M2 proteins) showing a typical SDS-PAGE pattern of novirabdoviruses. The causative agent was completely neutralyzed by anti-VHSV (DF-59) serum but not by antiserum against IHNV or HIRRV. In the Western blot analyses, structure proteins of KRRV9601 were also cross-reacted with anti-VHSV (DF-59) serum but not with antiserum against IHNV or HIRRV. Additionaly, the KRRV-9601 showed positive reactions in PCR amplification with specific primers to VHSV and in the IFAT with anti-VHSV serum. Based on these results, the causative virus, KRRV-9601, is identified as VHSV. The experimental infection using KRRV-9601 resulted in the same disease states with reisolation of the virus. These results indicate that VHSV was the causative agent of the natural epizootic. Thus, this is a first report of an outbreak of VHSV infection in cultured fish in Japan. As mentioned earlier, the first reported American type of VHSV (Obama \#25 isolate) was isolated from the wild populations of hirame caught in Wakasa Bay, Japan, in 1999 (Takano et al. 2000). However, KRRV-9601 could not be considered identical with Obama \#25 because slight differences were observed in the relative mobility of the G, M1 and M2 proteins between these 2 VHSV isolates. Based on the phylogenetic analysis of nucleotide sequences of G protein gene, VHSV isolates were clusted into three geno-groups; American type, Scotland type and traditional Europian type (Benmansour et al. 1997, Stone et al. 1997). Although the Obama \#25 isolate is closely related to the American type, genetic relatedness between KRRV-9601 and Obama \#25 isolates is not clear in the present results.

$\mathrm{BF}-2$ is the most susceptible cell line for VHSV isolation (Olesen \& Jørgensen 1992) while CHSE-214, EPC, FHM, PG and RTG-2 are also useful (Wolf 1988). In the present study, it was revealed that a marine fish cell line, RSBK-2, was also markedly susceptible to VHSV as well as FHM and BF-2 while EPC cell line showed a lower susceptibility against KRRV-9601; thus, RSBK-2 is a very useful cell line for isolating VHSV from marine fish species. On the other hand, natural outbreaks of VHSV infection in farmed marine species such as turbot have occurred in Scotland at 13 to $14^{\circ} \mathrm{C}$ and in Germany at around $15^{\circ} \mathrm{C}$ (Schlotfeldt et al. 1991, Ross et al. 1994) Additionaly, de Kinkelin \& Scherrer (1970) reported that the range of VHSV replication in FHM cells extends from 4 to about $20^{\circ} \mathrm{C}$, but peak yields are reached at 10 to $14^{\circ} \mathrm{C}$. In the present study, the same dependencies on temperature were observed in natural occurrences of VHSV infection in cultured hirame, and in the replication of KRRV-9601 in RSBK-2 cells. Thus, lower water temperature is one of the predisposing factors on the pathogenicity of KRRV-9601 against hirame.

In Japan, farmed hirame experienced mass mortalities during the 1980s due to HIRRVD (Kimura et al. 1986, 1989), although this disease has not been prevalent in recent years. The diseased fish infected with HIRRV usually displayed severe hemorrhage in the lateral musculature and in visceral organs including gonads, pale gill coloration, and abdominal distention due to ascites. In contrast, the present disease caused by VHSV showed similar pathological signs; however, hemorrhagic signs were rare in any organs. Moreover, edematous and congestive signs were prominent, and clear ascitic fluid also accumulated in the pericardial cavity as well as peritoneal cavity.

The results of the experimental infections using the present isolate indicated that VHSV is apparently pathogenic to hirame and its pathogenicity decreases with increases in the body weight of the host fish; however, mortality still occurs even in large fish weighing about $1000 \mathrm{~g}$. In many cases of natural outbreaks, market-size groups experienced mass mor- 

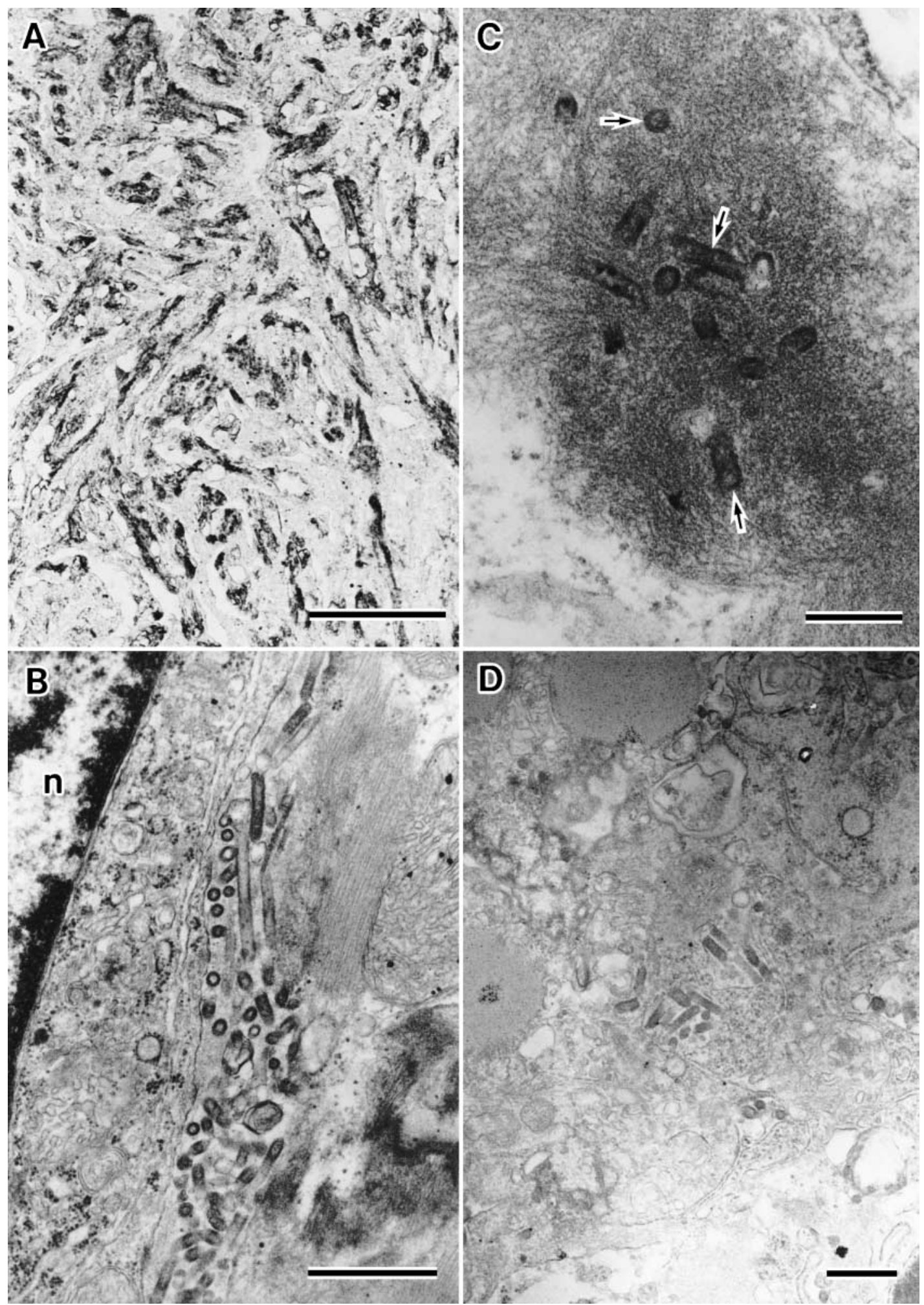

Fig. 8. Paralichthys olivaceus in experimental infection. (A) Necrotized muscle fibers of the myocardium markedly show positive reactions of virus antigens by immunohistochemical staining. Scale bar $=100 \mu \mathrm{m}$. (B) Electron micrograph of the necrotized cardiac muscle cells shows many virions with bullet, cone, or bacilliform shapes outside of the cell. $\mathrm{n}$ : nucleus. Scale bar $=500 \mathrm{~nm}$. (C) High magnification view of an inclusion body in the sarcoplasm of necrotized cardiac muscle cell. Inclusion body consists of granular substance and many nucleocapsid-like structures (arrows). Scale bar $=200 \mathrm{~nm}$. (D) Electron micrograph of the necrotized splenocytes. Many virions appear among degenerated organella of the fragmented cell. Scale bar $=500 \mathrm{~nm}$. 
talities. From these observations, VHSV appears to be a threat to hirame.

Histopathological changes due to VHSV infection have been reported in rainbow trout (Yasutake \& Rasmussen 1968, Yasutake 1970, 1975, Horlyck et al. 1984, Smail \& Munro 1989), pike (Meier \& Jørgensen 1980), sea bass (Castric \& de Kinkelin 1984), Pacific cod (Meyers et al. 1992), turbot (Ross et al. 1994) and Pacific herring (Kocan et al 1997, Marty et al. 1998). Each of these species except Pacific cod showed the same histopathological signs, including necrotic changes in the liver, spleen, hematopoietic tissue and pancreatic acini. Pacific cod displayed only dermal lesions. In turbot, necrotic lesions were also found in the heart. Hemorrhagic lesions in the lateral musculature, as indicated by the name of the disease (VHS), were most severe in rainbow trout, which was first species in which VHS was described. VHS of rainbow trout caused intermuscular and intrahepatic hemorrhages due to damage of capillary and sinusoid endothelia that were infected with VHSV (de Kinkelin et al. 1979, Evensen et al. 1994). The severity of hemorrhaging varied among fish species and appeared to depend on the susceptibility of capillary endothelial cells to VHSV. Hemorrhagic lesions were also evident in pike, sea bass and turbot whereas hemorrhagic changes were less obvious in Pacific herring as well as in hirame in the present study. Among other rhabdoviruses, HIRRV markedly infects capillary endothelial cells, resulting in severe hemorrhage within the lateral musculature as well as various visceral organs (Isshiki, Nagano \& Miyazaki unpubl. data). Spring viremia of carp (SVC) virus has produced similar lesions (Smail \& Munro 1989) and dermatitis of eel (DE) rhabdovirus has caused hemorrhage in the dermis of Japanese eels Anguilla japonica (Kobayashi \& Miyazaki 1996). Conversely, IHNV has appeared less infective to capillary endothelial cells of salmonid fishes because hemorrhage has not always occurred (Yasutake \& Amend 1972).

The diseased hirame in the present study displayed histopathological lesions that were very similar to many of those described in the above fishes. In the diseased hirame, TEM observations also confirmed the association of VHSV virions with necrotic cells in the spleen and hematopoietic tissue, and necrotic myocardium. Although lesions of the heart were examined in diseased turbot and Pacific herring, they were not examined in diseased rainbow trout, pike or Pacific cod in the previous studies. In the present study, diseased hirame had severe necrotic lesions in the myocardium that were similar to those observed in turbot. TEM also revealed the formation of inclusion bodies in necrotic cells of the myocardium. The feature of inclusion bodies is the same as those found in infected RSBK-2 cells and RTG-2 cells (Zwillenberg et al. 1965, de Kinkelin \& Scherrer 1970). Thus, the formation of inclusion bodies in the infected cells is distinctive in VHSV of the genus Novirhabdovirus. Diseased hirame displayed marked congestion in visceral organs such as the hepato pancreas, spleen and hematopoietic tissue. The congestion likely resulted from cardiac failure due to myocardium necrosis. Pacific herring has showed myocardial mineralization significantly associated with VHSV (Marty et al. 1998), which appears to be due to calsium deposition in necrotized myocardium. Although cardiac lesions were not histopathologically observed, congestive changes were present in diseased rainbow trout (Yasutake \& Rasmussen 1968), which also strongly suggested the presence of cardiac lesions. Myocardiac necrosis accompanied by inflammatory reactions was considered to be the main pathological change that induced systemic circulatory disturbances and led to death. Thus, necrotizing myocarditis could be considered a pathognomonic sign of VHSV infection in hirame. Based on histopathological findings, we would like to term VHSV infection of hirame 'VHS-viral Necrotizing Myocarditis of Hirame'.

Acknowledgements. We thank Dr N. J. Olesen (Danish Veterinary Laboratory) and Dr M. Yoshimizu (Hokkaido University) for kindly providing antisera against VHSV (DK F59) and IHNV (ChAb). We also thank the staff of Kagawa Prefectural Sea Farming Center for providing experimental fish.

\section{LITERATURE CITED}

Amos K, Thomas J, Hopper K (1998) A case history of adaptive management strategies for viral hemorrhagic septicemia virus (VHSV) in Washington state. J Aquat Anim Health 10:152-159

Benmansour A, Basurco B, Monnier AF, Vende P, Winton JR, de Kinkelin P (1997) Sequence variation of the glycoprotein gene identifies three distinct lineages within field isolates of viral haemorrhagic septicaemia virus, a fish rhabdovirus. J Gen Virol 78:2837-2846

Brunson R, True K, Yancey J (1989) VHS virus isolated at Makah National Fish Hatchery. Fish Health Sect Am Fish Soc Newsl 17:3-4

Castric J, de Kinkelin P (1980) Occurrence of viral haemorrhagic septicaemia in rainbow trout Salmo gairdneri Richardson reared in sea water. J Fish Dis 3:21-27

Castric J, de Kinkelin P (1984) Experimental study of the susceptibility of two marine fish species, sea bass (Dicentrarchus labrax) and turbot (Scophthalmus maximus), to viral haemorrhagic septicaemia. Aquaculture 41:203-212

de Kinkelin P, Scherrer R (1970) Le virus d'Egtved. I. Stabilite, developpment et structure du virus de la souche danoise F1. Ann Rech Vet 1:17-30

de Kinkelin P, Chilmonczyk S, Dorson M, Le Berre M, Baudouy AM (1979) Some pathogenic facets of rhabdoviral infection of salmonid fish. In: Bachmann PA (ed) Symposia 
on microbiology: mechanism of viral pathogenesis and virulence. WHO Collaborating Centre for Collection and Education of Data on Comparitive Virology, Munich, p 357-375

Evensen O, Meier W, Wahli T, Olsen NJ, Jørgensen PEV, Hastein T (1994) Comparison of immunohistochemistry and virus cultivation for detection of viral haemorrhagic septicaemia virus in experimentally infected rainbow trout Oncorhynchus mykiss. Dis Aquat Org 20:101-109

Gravell M, Malsburger RG (1965) A permanent cell line from the fathead minnow (Pimephales promelas). Ann N Y Acad Sci 126:555-565

Horlyck V, Mellergard S, Dalsgaard I, Jørgensen PEV (1984) Occurrence of VHS in Danish maricultured rainbow trout. Bull Eur Assoc Fish Pathol 4:11-13

Jørgensen PEV (1980) Egtved virus: the susceptibility of brown trout and rainbow trout to eight isolates and significance of the findings for the VHS control. In: Ahne W (ed) Fish disease. Third COPRAQ Session. Springer Verlag, Berlin, p 3-7

Kimura T, Yoshimizu M (1991) Viral diseases of fish in Japan. Annu Rev Fish Dis 1:67-82

Kimura T, Yoshimizu M, Gorie S (1986) A new rhabdovirus isolated in Japan from cultured hirame (Japanese flounder) Palalichthys olivaceus and ayu Plecoglossus altivelis. Dis Aquat Org 1:209-217

Kimura T, Yoshimizu M, Oseko N, Nishizawa T (1989) Rhabdovirus olivaceus (Hirame rhabdovirus). In: Ahne W, Kurstak E (eds) Viruses of lower vertebrates. Springer Verlag, Berlin, p 388-395

Kobayashi T, Miyazaki T (1996) Rhabdoviral dermatitis in Japanese eel, Anguilla japonica. Fish Pathol 31:183-190 (in Japanese with English abstract)

Kocan R, Bradley M, Elder N, Meyers T, Batts B, Winton J (1997) North American strain of viral hemorrhagic septicemia virus is highly pathogenic for laboratory reared Pacific herring. J Aquat Anim Health 9:279-290

Kusuda R, Kawarasaki A (1993) Establishment and characterization of a cell line derived from the kidney of red sea bream, Pagrus major. Suisanzoshoku 41:455-460 (in Japanese with English abstract)

Laemmli UK (1970) Cleavage of structural proteins during the assembly of the head of bacteriophage T4. Nature 227: 680-685

Lannan CN, Winton JR, Fryer JL (1984) Fish cell lines: establishment and characterization of nine cell lines from salmonids. In Vitro 20:671-676

Marty GD, Freiberg EF, Meyers TR, Wilcock J, Farver TB, Hinton DE (1998) Viral hemorrhagic septicemia virus, Ichthyophonus hoferi, and other causes of morbidity in pacific herring Clupea pallasi spawning in Prince William Sound, Alaska, USA. Dis Aquat Org 32:15-40

Meier W, Jørgensen PEV (1980) Isolation of VHS virus from pike fry (Esox lucius) with hemorrhagic symptoms. In: Ahne W (ed) Fish disease. Springer Verlag, Berlin, p 8-17

Meyers TR, Winton JR (1995) Viral hemorrhagic septicemia in North America. Annu Rev Fish Dis 5:3-24

Meyers TR, Sullivan J, Emmenegger E, Follett J, Short S, Batts WN, Winton JR (1992) Identification of viral hemorrhagic septicemia virus isolated from Pacific cod Gadus macrocephalus in Prince William Sound, Alaska, USA. Dis Aquat Org 12:167-175

Miller TA, Rapp J, Wastlhuber U, Hoffmann RW, Enzmann PJ (1998) Rapid and sensitive reverse transcriptase polymerase chain reaction based detection and differential diagnosis of fish pathogenic rhabdoviruses in organ samples and cultured cells. Dis Aquat Org 34:13-20
Mortensen HF, Heuer OE, Lorenzen N, Otte L, Olesen NJ (1999) Isolation of viral haemorrhagic septicaemia virus (VHSV) from wild marine fish species in Baltic Sea, Kattegat, Skagerrak and the North Sea. Virus Res 63:95-106

Nishizawa T, Yoshimizu M, Winton J, Ahne W, Kimura T (1991) Characterization of structural proteins of hirame rhabdovirus, HRV. Dis Aquat Org 10:167-172

Olesen NJ, Jørgensen PEV (1992) Comparative susceptibility of three fish cell lines to Egtved virus, the virus of viral haemorrhagic septicaemia (VHS). Dis Aquat Org 12:235-237

Olesen NJ, Lorenzen N (1999) Production of neutralizing antisera against viral hemorrhagic septicemia (VHS) virus by intravenous injections of rabbits. J Aquat Anim Health 11:10-16

Rasmussen CJ (1965) A biological study of the Egtved disease (InuL). Ann N Y Acad Sci 126:427-460

Ross K, McCarthy U, Huntly PJ, Wood BP, Stuart D, Rough EI, Smail DA, Bruno DW (1994) An outbreak of viral haemorrhagic septicaemia (VHS) in turbot (Scophthalmus maximus) in Scotland. Bull Eur Assoc Fish Pathol 14:213-214

Schlotfeldt HJ, Ahne W, Jørgensen PEV, Glende W (1991) Occurrence of viral haemorrhagic septicaemia in turbot (Scophthalmus maximus) - a natural outbreak. Bull Eur Assoc Fish Pathol 11:105-107

Smail DA (1999) Viral haemorrhagic septicaemia. In: Wood PTK, Bruno DW (eds) Fish disease and disorders, Vol 3. Viral, bacterial and fungal infections. CABI Publishing, New York, p 123-147

Smail DM, Munro ALS (1989) The virology of teleosts. In: Roberts RJ (ed) Fish pathology, 2nd edn. Bailliere Tindall, London, p 173-186

Snow M, Smail DA (1999) Experimental susceptibility of turbot Scophthalmus maximus to viral haemorrhagic septicaemia virus isolated from cultivated turbot. Dis Aquat Org 38:163-168

Stone DM, Way K, Dixon PF (1997) Nucleotide sequence of the glycoprotein gene of viral haemorrhagic septicaemia (VHS) viruses from different geographical areas: a link between VHS in farmed fish species and viruses isolated from North Sea cod (Gadus morhua L.). J Gen Viol 78: 1319-1326

Takano R, Nishizawa T, Arimoto M, Muroga K (2000) Isolation of viral hemorrhagic septicemia virus (VHSV) from wild Japanese flounder, Paralichthys olivaceus. Bull Eur Assoc Fish Pathol 20:186-193

Tomasec J, Fijan N (1971) Virusne bolestiriba (viral disease of fish). Final report on research under a part of project 6 n/1966, Zagreb

Towbin H, Staehelin T, Gordon J (1979) Electrophoretic transfer of protein from polyacrylamide gels to nitrocellulose sheets: procedure and some applications. Proc Natl Acad Sci USA 76:4350-4354

Walker PJ, Benmansour A, Calisher CH, Dietzgen R, Fang RX, Jackson AO, Kurath G, Leong JC, Nadin Davies S, Tesh RB, Tordo N (2000) Family Rhabdoviridae. In: van Regenmortel MHV (ed) Virus taxonomy. Seventh report of the international committee for taxonomy of viruses. Academic Press, San Diego, p 563-583

Winton JR, Batts WN, Nishizawa T, Stehr CM (1989) Characterization of the first North American isolates of viral hemorrhagic septicemia virus. Fish Health Sect Am Fish Soc Newsl 17:2-3

Wolf K (1988) Viral hemorrhagic septicemia. In: Wolf K (ed) Fish viruses and fish viral diseases. Cornell University Press, Ithaca, p 217-249

Wolf K, Quimby MC (1962) Established eurythermic line of fish cells in vitro. Science 135:1065-1066 
Wolf K, Gravell M, Malsberger RG (1966) Lymphocystis virus: isolation and propagation in centrarchid fish cell lines. Science 151:1004-1005

Yasutake WT (1970) Comparative histopathology of epizootic salmonid virus diseases. In: Snieszko SF (ed) A symposium on diseases of fishes and shellfishes. American Fisheries Society, Washington DC, p 341-350

Yasutake WT (1975) Fish viral diseases: clinical, histopathological, and comparative aspects. In: Ribelin WE, Migaki $\mathrm{G}$ (eds) The pathology of fishes. The University of Wisconsin Press, Madison, p 247-271

Editorial responsibility: Jo-Ann Leong,

Corvallis, Oregon, USA
Yasutake WT, Amend DF (1972) Some aspects of pathogenesis of infectious hematopoietic necrosis (IHN). J Fish Biol $4: 261-264$

Yasutake WT, Rasmussen CJ (1968) Histopathogenesis of experimentally induced viral hemorrhagic septicemia in fingerling raibow trout (Salmo gairdneri). Bull Off Int Epizoot 69:977-984

Zwillenberg LO, Jensen MH, Zwillenberg HHL (1965) Electron microscopy of the virus of viral haemorrhagic septicaemia of rainbow trout (Egtved virus). Arch Ges Virusforsch 17:1-19

Submitted: February 5, 2001; Accepted: May 14, 2001 Proofs received from author(s): October 22, 2001 